\title{
Front Matter: Volume 8470
}

"Front Matter: Volume 8470," Proc. SPIE 8470, Thin Film Solar Technology IV, 847001 (31 October 2012); doi: 10.1117/12.2011786

SPIE Event: SPIE Solar Energy + Technology, 2012, San Diego, California, United SPIE. States 


\section{PROCEEDINGS OF SPIE}

\section{Thin Film Solar Technology IV}

Louay A. Eldada

Editor

12-13 August 2013

San Diego, California, United States

Sponsored and Published by

SPIE 
The papers included in this volume were part of the technical conference cited on the cover and title page. Papers were selected and subject to review by the editors and conference program committee. Some conference presentations may not be available for publication. The papers published in these proceedings reflect the work and thoughts of the authors and are published herein as submitted. The publisher is not responsible for the validity of the information or for any outcomes resulting from reliance thereon.

Please use the following format to cite material from this book:

Author(s), "Title of Paper," in Thin Film Solar Technology IV, edited by Louay A. Eldada, Proceedings of SPIE Vol. 8470 (SPIE, Bellingham, WA, 2012) Article CID Number.

ISSN: 0277-786X

ISBN: 9780819491879

Published by

SPIE

P.O. Box 10, Bellingham, Washington 98227-0010 USA

Telephone +1 3606763290 (Pacific Time) · Fax +1 3606471445

SPIE.org

Copyright (C) 2012, Society of Photo-Optical Instrumentation Engineers.

Copying of material in this book for internal or personal use, or for the internal or personal use of specific clients, beyond the fair use provisions granted by the U.S. Copyright Law is authorized by SPIE subject to payment of copying fees. The Transactional Reporting Service base fee for this volume is $\$ 18.00$ per article (or portion thereof), which should be paid directly to the Copyright Clearance Center (CCC), 222 Rosewood Drive, Danvers, MA 01923. Payment may also be made electronically through CCC Online at copyright.com. Other copying for republication, resale, advertising or promotion, or any form of systematic or multiple reproduction of any material in this book is prohibited except with permission in writing from the publisher. The CCC fee code is 0277-786X/12/\$18.00.

Printed in the United States of America.

Publication of record for individual papers is online in the SPIE Digital Library.

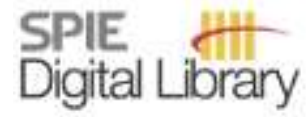

SPIEDigitalLibrary.org

Paper Numbering: Proceedings of SPIE follow an e-First publication model, with papers published first online and then in print and on CD-ROM. Papers are published as they are submitted and meet publication criteria. A unique, consistent, permanent citation identifier (CID) number is assigned to each article at the time of the first publication. Utilization of CIDs allows articles to be fully citable as soon as they are published online, and connects the same identifier to all online, print, and electronic versions of the publication. SPIE uses a six-digit CID article numbering system in which:

- The first four digits correspond to the SPIE volume number.

- The last two digits indicate publication order within the volume using a Base 36 numbering

system employing both numerals and letters. These two-number sets start with 00, 01, 02, 03, 04, $05,06,07,08,09,0 A, 0 B \ldots$. 0Z, followed by 10-1Z, 20-2Z, etc.

The CID Number appears on each page of the manuscript. The complete citation is used on the first page, and an abbreviated version on subsequent pages. Numbers in the index correspond to the last two digits of the six-digit CID Number. 


\section{Contents}

$\checkmark$ Conference Committee

ix Introduction

\section{ADVANCES IN THIN FILM SILICON PV}

847007 Double-pulsed PECVD synthesis of hydrogenated nanocrystalline silicon thin films [8470-7] J. D. Fields, Colorado School of Mines (United States); J. B. Gallon, J. Hu, E. Valentich, MVSystems, Inc. (United States); P. C. Taylor, Colorado School of Mines (United States); A. Madan, MVSystems, Inc. (United States)

847008 Experiments with resonant thin-film hydrogenated amorphous silicon solar cells [8470-8] T. Khaleque, R. Magnusson, The Univ. of Texas at Arlington (United States)

847009 High-rate deposition of silicon thin film layers using linear plasma sources operated at very high excitation frequencies $(80-140 \mathrm{MHz}$ ) [8470-9]

B. Leszczynska, C. Strobel, S. Leszczynski, M. Albert, J. W. Bartha, Technische Univ. Dresden (Germany); U. Stephan, J. Kuske, Forschungs- und Applikationslabor Plasmatechnik GmbH (Germany)

\section{ADVANCES IN C-SI PV}

$8470 \mathrm{OB}$ Silicon epitaxy below $200^{\circ} \mathrm{C}$ : towards thin crystalline solar cells [8470-11]

R. Cariou, LPICM, CNRS, Ecole Polytechnique (France) and III-V lab: Alcatel-Lucent Bell Labs France, Thales Research and Technology and CEA-LETI (France); R. Ruggeri, LPICM, CNRS, Ecole Polytechnique (France) and Univ. degli Studi di Messina (Italy); P. Chatterjee, Indian Association for the Cultivation of Science (India); J.-L. Gentner, III-V lab: AlcatelLucent Bell Labs, Thales Research and Technology and CEA-LETI (France); P. Roca i Cabarrocas, LPICM, CNRS, Ecole Polytechnique (France)

8470 OD Best practice quality control in solar module back sheet production [8470-14] R. Kobren, J. F. Jordon, DUNMORE Corp. (United States)

\section{NOVEL PV MATERIALS AND CHARACTERIZATION METHODS}

8470 OE High quality SnS van der Waals epitaxies on graphene buffer layer [8470-15]

W. Wang, K. K. Leung, W. K. Fong, S. F. Wang, Y. Y. Hui, S. P. Lau, C. Surya, The Hong Kong Polytechnic Univ. (Hong Kong, China) 
8470 OF Characterization and quality control of semiconductor wafers using time-correlated single photon counting [8470-16]

V. Buschmann, PicoQuant GmbH (Germany); S. Fore, PicoQuant North America, Inc. (United States); F. Koberling, PicoQuant GmbH (Germany); A. Knigge, Ferdinand-BraunInstitut (Germany); P. Kapusta, U. Ortmann, PicoQuant GmbH (Germany); M. Roczen, Helmholtz-Institut für Materialien und Energie (Germany); R. Erdmann, PicoQuant GmbH (Germany)

8470 OG Variable temperature Hall measurements on low-mobility materials [8470-17]

J. Lindemuth, Lake Shore Cryotronics, Inc. (United States)

$8470 \mathrm{OH} \quad$ Optical and structural properties of silver doped ZnSe thin films prepared by CSS and ion exchange process [8470-18]

A. Aqili, The Hashemite Univ. (Jordan); Z. Ali, Lawrence Berkeley National Lab. (United States) and Optics Labs. (Pakistan); Z. Hussain, Lawrence Berkeley National Lab. (United States)

847000 Properties of the thin-film solar cells with heterojunctions $\mathrm{CU}_{2} S-\mathrm{Cd}_{1-\mathrm{x}} \mathbf{Z n}_{\mathbf{x}} \mathrm{S}$ and $\mathrm{Cu}_{2} \mathrm{Se}-\mathrm{Cd}_{1-x} \mathrm{Zn}_{\mathbf{x}} \mathrm{Se}$ [8470-19]

M. A. Jafarov, E. F. Nasirov, Baku State Univ. (Azerbaijan)

CIGS PV MODELING, FABRICATION, AND CHARACTERIZATION

$8470 \mathrm{OL} \quad$ Understanding CIGS device performances through photoreflectance spectroscopy [8470-21]

A. Moreau, IM2NP, CNRS, Aix-Marseille Univ. (France) and NEXCIS, Photovoltaic Technology Rousset (France); D. Fuertes-Marron, I. Artacho, Technical Univ. of Madrid (Spain);

L. Escoubas, J.-J. Simon, IM2NP, CNRS, Aix-Marseille Univ. (France); C. M. Ruiz, IM2NP, CNRS, Aix-Marseille Univ. (France) and NEXCIS, Photovoltaic Technology Rousset (France);

$\checkmark$. Bermudez, NEXCIS, Photovoltaic Technology Rousset (France)

$8470 \mathrm{OM}$ Investigation of the (Cu,Ga)InSe 2 thin film with different pairs of $\mathrm{CuGa/In}$ sputtered layers [8470-22]

Y.-T. Hsu, K.-F. Huang, National Chiao Tung Univ. (Taiwan); S.-I. Tsai, W.-H. Lan, National Univ. of Kaohsiung (Taiwan); M. Yueh, National Cheng Kung Univ. (Taiwan); J.-C. Lin,

K.-J. Chang, W.-J. Lin, Chung-Shan Institute of Science and Technology (Taiwan)

\section{TRANSPARENT CONDUCTING OXIDES}

8470 OP Transparent conducting materials: overview and recent results [8470-25]

J. van Deelen, A. Illiberi, A. Hovestad, I. Barbu, L. Klerk, P. Buskens, TNO Science and

Industry (Netherlands)

POSTER SESSION

8470 OS Extraction of optical properties and thickness of silicon-rich oxide films from ellipsometry measurement [8470-29]

S. Lin, I. Perez Wurfl, Y. Feng, The Univ. of New South Wales (Australia)

iv 
8470 OT Infrared and $x$-ray absorption studies of CdTe thin films [8470-30]

W. Wang, Nanjing Univ. (China); Y. C. Yang, National Taiwan Univ. (Taiwan); T.-S. Chan, National Synchrotron Radiation Research Ctr. (Taiwan); P. Chen, Nanjing Univ. (China); T.-R. Yang, National Taiwan Normal Univ. (Taiwan); Z. C. Feng, National Taiwan Univ. (Taiwan)

$847011 \quad$ Novel techniques to improve the light harvesting of thin film solar cells [8470-38] S. Castelletto, Macquarie Univ. (Australia); A. Boretti, Missouri Univ. of Science \& Technology (United States)

Author Index 
Proc. of SPIE Vol. $8470847001-6$

Downloaded From: https://www.spiedigitallibrary.org/conference-proceedings-of-spie on 26 Apr 2023 Terms of Use: https://www.spiedigitallibrary.org/terms-of-use 


\section{Conference Committee}

Symposium Chair

Martha Symko-Davies, National Renewable Energy Laboratory

(United States)

Conference Chair

Louay A. Eldada, Amprius, Inc. (United States)

Conference Program Committee

Bulent Basol, EncoreSolar, Inc. (United States)

Howard M. Branz, National Renewable Energy Laboratory

(United States)

Paola Delli Veneri, ENEA (Italy)

David S. Ginley, National Renewable Energy Laboratory

(United States)

Ivan Gordon, IMEC (Belgium)

William N. Shafarman, University of Delaware (United States)

Ayodhya N. Tiwari, EMPA (Switzerland)

Baojie Yan, United Solar Ovonic, LLC (United States)

Session Chairs

1 Nanostructured Thin Film PV

Louay A. Eldada, Amprius, Inc. (United States)

2 Advances in Thin Film Silicon PV

Louay A. Eldada, Amprius, Inc. (United States)

3 Advances in C-Si PV

Vivek B. Shah, Washington University in St. Louis (United States)

4 Novel PV Materials and Characterization Methods

Jeehwan Kim, IBM Thomas J. Watson Research Center (United States)

5 CIGS PV Modeling, Fabrication, and Characterization

Louay A. Eldada, Amprius, Inc. (United States) 
Proc. of SPIE Vol. $8470847001-8$

Downloaded From: https://www.spiedigitallibrary.org/conference-proceedings-of-spie on 26 Apr 2023 Terms of Use: https://www.spiedigitallibrary.org/terms-of-use 


\section{Introduction}

The fourth Thin Film Solar Technology conference was held this year at the SPIE Solar Energy + Technology symposium. The program was strong with stimulating talks from various areas in the field, ensuring a well-attended and successful event. The conference included speakers from leading international academic institutions, government laboratories, and industry.

This volume features contributions from scientists and engineers in the general area of Thin Film Solar Technology, with special emphasis on Thin Film Photovoltaics (TF PV). Thin film solar technologies are a compelling alternative to conventional crystalline silicon solar technologies because they offer a cost reduction potential, driven mainly by the need for a lower amount of material, as well as the possibility of monolithic integration. It is important to note, however, that silicon pricing has continued to drop dramatically this year, challenging TF PV manufacturers to further improve the efficiency and reduce the cost of their modules. As a result, this year has seen continued shake-out in the TF PV space, leaving fewer companies in each technology area standing, as well as significant consolidation activity through mergers and acquisitions. The PV industry came out of this period of change stronger.

To illustrate the breadth of topics covered in this conference, we mention just a few of the papers presented in each session. The first session dealt with nanostructured thin film PV. Jeehwan Kim et al. from the IBM Thomas J. Watson Research Center presented a talk on the progress and challenges in threedimensional thin film silicon PV, with a focus on nanocone-based solar cells. Ulrich Paetzold et al. from Forschungszentrum Jülich, Germany, proposed plasmonic reflection grating back contacts for thin film silicon solar cells. Vivek Shah and his colleagues from the group of Prof. Pratim Biswas at Washington University in St. Louis tackled nature-inspired nanostructures for enhanced performance using a single-step process to synthesize bio-hybrid and bio-mimetic solar PV devices. The second session focused on advances in thin film silicon PV. Jeremy Fields and coworkers from the Colorado School of Mines and MVSystems proposed synthesizing hydrogenated nanocrystalline silicon thin films using a double-pulsed PECVD process. Tanzina Khaleque from Prof. Robert Magnusson's group at the University of Texas at Arlington described experiments with resonant thin film hydrogenated amorphous silicon solar cells. Barbara Leszczynska and coworkers from the Technische Universität Dresden and the Forschungs- und Applikationslabor Plasmatechnik, Germany, described the high-rate deposition of silicon thin film layers using linear plasma sources operated at very high excitation frequencies (80-140 MHz). Chang Su Kim et al. from the Korea Institute of Materials Science described innovative amorphous silicon and organic hybrid tandem thin film solar cells. 
The third session dealt with advances in crystalline silicon PV. Romain Cariou and his colleagues from the Ecole Polytechnique, France, and their collaborators from Università degli Studi di Messina, Italy, and the Indian Association for the cultivation of Science, described a novel process for the epitaxy of silicon below $200^{\circ} \mathrm{C}$. Louay Eldada from Amprius described hybrid PV systems that integrated high-efficiency crystalline silicon panels, long-lifetime energy storage solutions, and back-up generators; these systems were deployed globally for rural electrification, mine exploration, irrigation, and desalination. The fourth session covered novel PV materials and characterization methods and the emerging field of CZTS (copper zinc tin sulfide/selenide) solar cells. Wei Wang et al. from the Hong Kong Polytechnic University described SnS van der Waals epitaxies on graphene buffer layer. Volker Buschmann and his colleagues from PicoQuant, Germany, and their coworkers from the Ferdinand Braun Institut and the Helmholtz Institut für Materialien und Energie, Germany, discussed the characterization and quality control of semiconductor wafers using timecorrelated single photon counting. Akram Aqili from the Hashemite University, Jordan, and his collaborators from the Optics Laboratories, Pakistan and the Lawrence Berkeley National Laboratory, described the optical and structural properties of silver doped ZnSe thin films prepared by CSS and ion exchange process. Kaushik Choudhury and his colleagues from DuPont covered the topic of CZTS solar cells from inks in their talk on solution chemical routes to high efficiency Cu2ZnSn(S,Se) thin-film solar cells.

The fifth session focused on CIGS (copper indium gallium selenide) PV modeling, fabrication, and characterization. Mustafa Pinarbasi of SoloPower gave an invited talk on the processing and performance of low weight flexible CIGS cells and modules. Antonin Moreau and coworkers from the Institut Matériaux Microélectronique Nanosciences de Provence and NEXCIS, France, and the Technical University of Madrid, Spain, discussed characterizing CIGS devices using photoreflectance spectroscopy. Yu-Ting Hsu and coworkers from the National Chiao Tung University, the National University of Kaohsiung, the National Cheng Kung University and the Institute of Science and Technology, Taiwan, presented their results on studies of CIGS thin films with different pairs of CUGa/In sputtered layers. Finally, the last session of the conference, the sixth session, dealt with transparent conducting oxides. Maxwell Mageto and coworkers from Uppsala University, Sweden, and Kenya's University of Science and Technology and Moi University, discussed the electrical and optical properties of TiO2: $\mathrm{Nb}$ thin films prepared by the spray pyrolysis technique, and Thomas Gennett and colleagues from David Ginley's group at the National Renewable Energy Laboratory (NREL) presented an invited talk on innovative amorphous InZnO transparent conductors that improve the Epi-Si heterojunction PV performance.

Although this volume cannot include all the recent important work in the vast field of thin film solar technologies, it does cover a significant cross section of the advances happening globally, and it provides a roadmap for this fast-growing 
and exciting field by presenting the cutting-edge work and the visions of leading experts who are actively inventing the future.

Louay A. Eldada

Proc. of SPIE Vol. $8470847001-11$

Downloaded From: https://www.spiedigitallibrary.org/conference-proceedings-of-spie on 26 Apr 2023 Terms of Use: https://www.spiedigitallibrary.org/terms-of-use 
Proc. of SPIE Vol. $8470847001-12$

Downloaded From: https://www.spiedigitallibrary.org/conference-proceedings-of-spie on 26 Apr 2023 Terms of Use: https://www.spiedigitallibrary.org/terms-of-use 